\title{
Study Regarding the Capacity of Self-assembling Peptides to Remineralize the Acute and Chronic Incipient Caries Lesions
}

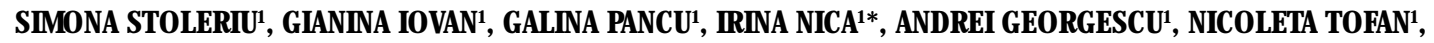 \\ SORIN ANDRIAN ${ }^{1 *}$, DAN BUHATEL ${ }^{2}$ \\ ${ }^{1}$ Grigore T. Popa University of Medicine and Pharmacy lasi, Faculty of Dental Medicine, 16 Universitatii Str., 700115, Iasi, Romania \\ 2 Iuliu Haieganu University of Medicine and Pharmacy Cluj-Napoca, Faculty of Dental Medicine, 8 Victor Babes Str., 400000, \\ Cluj Napoca, Romania
}

\begin{abstract}
The aim of the study was to evaluate the effect of biomimetic self assembling peptides $\left(P_{11}-4\right)$ on remineralization of acute and chronic incipient enamel lesions by microhardness analysis. Ten extracted permanent human teeth having incipient white spot lesions and ten extracted teeth with brown spot lesions on proximal surfaces were included in this study. Half of the extern surface of the lesions was covered with flowable composite resin (Vertise flow, Kerr Corporation) and served as negative control site. On the other half Curodont ${ }^{\text {TM }}$ Protect gel (Credentis AG, Windisch, Switzerland) was applied 2 times a week, 8 weeks (study). The teeth were cut mesio-distally using diamond disks under cooling water, perpendicularly to the extern surface of the lesions, in order that both areas (negative control and study) to be evaluated. The opposite proximal sound enamel on each section served as positive control. The subsurface microhardness of the enamel samples was determined using digital microhardness tester (MicroVickers Hardness System

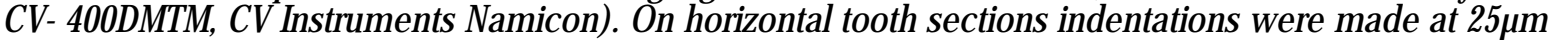
(A1), $75 \mu \mathrm{m}$ (A2), $125 \mu \mathrm{m}$ (A3), $175 \mu \mathrm{m}$ (A4), $225 \mu \mathrm{m}$ (A5), and $275 \mu \mathrm{m}$ (A6) bellow the extern surface of the lesions. For white spot and brown spot caries lesions, in both negative control and study groups, the VHN values increased from A1 to A6 areas. In study group VHN values were higher than in negative control group irrespective of the area of examination. The lowest VHN value was registered in negative control A1 area and the highest in study group A6 area. In all six areas of investigation, VHN values in negative control and study groups were lower than the values in positive control group. The use of self-assembling peptides on white spot and brown spot caries lesions increase the hardness of these lesions in the deeper layers of the lesions.
\end{abstract}

Keywords: remineralization, self assembling peptides, white spotlesion, brown spotlesion, microhardness

Remineralization can be defined as the process of ion deposition into crystal voids in demineralized enamel that produce net mineral gain [1]. Generally, calcium and phosphate ions are supplied from an extern source to the tooth surface. In order that remineralization to occur, partially demineralized crystals must be exposed into direct contact to oversaturated fluids. Ideally, the remineralization agent must precipitate onto the partially demineralized dental structure and must lead to a more stable and less soluble apatite comparing to the one in the original tissues.

Biomimetic remineralization represents the natural repair process which is specific for the body of subsurface non-cavitated caries lesions. Calcium and phosphate ions with the help of fluoride ions rebuild a new surface of the demineralized subsurface crystals. These remineralized crystals are less soluble than the original mineral and are significantly more resistant to acid attacks [2-5].

The major objective in the treatment of an incipient caries lesion is a complete remineralization of subsurface lesion. The remineralizing agent must be able to pass through enamel surface and to reach the subsurface area. It was demonstrated that it is very difficult for calcium and phosphate ions to diffuse in the deepestlayers of the carious enamel. Calcium will be rapidly adsorbed on the superficial layer and it will precipitate onto the pores, thus blocking access towards the inside of the carious enamel lesion [6]. For this reason most of the remineralization process is limited to the superficial, virtually intact layer of the caries lesion. Itwas demonstrated in previous studies that fluoride, which was considered to be the gold standard in remineralization for many years, remineralizes the surface of early carious lesion on a thickness of approximately 40um [7]. Many studies pointed the importance of fluoride products in preventing the onset of the early caries lesions or in influencing the evolution of caries lesions [ 8,9$]$. Some researches have demonstrated that even the consumption of some foods which are rich in calcium ions can significantly increase the resistance of enamel and cement to acid attack [10]. The remineralization technology based on the complexes formed by phosphopeptides in caseinamorphous stabilized calcium phosphate (CPP-ACP) demonstrated good results when they were used before and after an acidic attack [11]. Another strategy to remineralize dental tooth structure is the use of products which contains calcium phosphate under a form similar to hydroxyapatite. Studies were concluded that such products have higher remineralization potential when compared to fluoride products in both primary and permanent enamel [12].

One of the latest strategy for incipient caries lesions remineralization is the use of self-assembling peptides (P11-4). In Curolox $®$ Technology P11-4 monomers applied on an incipient lesion diffuse within the pores and they assemble under a high ionic pressure in a 3D matrix as a scaffold that attract calcium phosphate in the saliva. New hydroxyapatite crystals are formed around this matrix and this biomimetic mineralization is capable to induce the regeneration of enamel and dentin. This $3 \mathrm{D}$ matrix mimics the role of matrix proteins of the enamel during the formation of the tooth. Some studies suggested that a 
single application of P11-4 is beneficial in the treatment of incipient caries lesions [13].

As a response to certain trigger environmental factors, P11-4 anionic peptide suffers a well-defined hierarchized structuring [ 14,15$]$ and forms three-dimensional fibrillar scaffolds leading to the synthesis of a new generation of well-defined biopolymers [16]. At certain concentrations of P11-4, the isotropic fluid with low viscosity turns into a mesomorphic elastomeric gel $(p H>0.7)$, after which the anionic groups of the lateral P11-4 chains will attract the Ca ions, inducing a new precipitation of hydroxyapatite.

P11-4 has the advantage of repairing naturally the carious lesions by regenerating the mineral itself. P11-4 is part of the new generation of peptides accelerating the process of biomimetic remineralization[17]. Curodont ${ }^{\text {mim }}$ Protect (Credentis AG, Windisch, Switzerland) is a product that incorporates the P11- 4 based Curolox"m technology, together with fluoride, and calcium phosphate. It was claimed that, when the gel is applied to the tooth, it enhanced hydroxyapatite crystallization for a period of three months $[18,19]$. In a study in vitro that evaluated the efficiency of this product in the regeneration of the demineralized enamel on the flat surfaces, significant results obtained after 8 and 12 weeks [20].

The aim of the present in vitro study was to evaluate the effect of biomimetic self assembling peptides (P11 4) on remineralization of acute and chronic incipient enamel caries lesions by microhardness analysis.

\section{Experimental part}

\section{Sample preparation}

Ten extracted permanent human teeth (molars and premolars) having incipient white spot lesions and ten extracted teeth with brown spot lesions on proximal surfaces were included in this study (figure $1 a$ and b). The conditions for teeth selection included proximal surfaces without plaque, debris, stains, restorations, sealants, or cavitated caries lesions, but with early signs of caries lesions: white or brown discoloration of enamel, mate, opaque appearance of enamel, rough surface when probing. The teeth were stored in periodically refreshed deionized distilled water until the start of the experiment.

Half of the extern surface of the lesions was covered with self-adhesive flowable composite resin (Vertise flow, Kerr Corporation) and served as negative control site. On

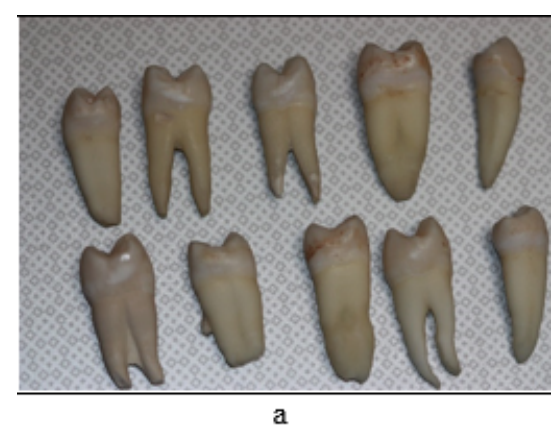

Fig. 1. The teeth with white spot (1a) and with brown spot (1b) lesions included in the

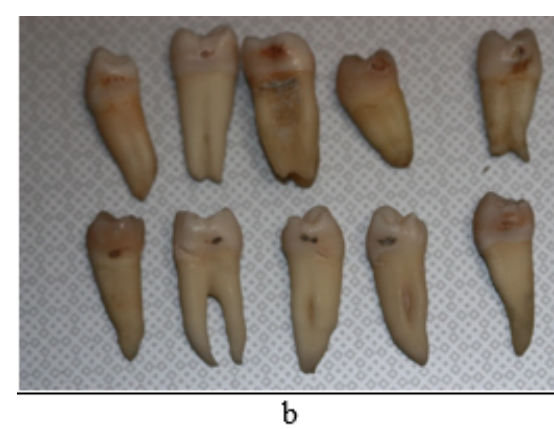
study the other half Curodont"' Repair (Credentis AG, Windisch, Switzerland -Lot CH180525) was applied 2 times a week, 8 weeks (study). On the surface of the teeth $2 \%$ sodium hypochlorite was applied for 20 seconds. In order to remove the inorganic deposits $35 \%$ phosphoric acid was used for $20 \mathrm{~s}$, then rinse with water and the teeth were dried using a dental unit air spray. The Curodont ${ }^{\prime \prime \prime}$ Repair applicator was activated by pushing the two cylinders together. After that the applicator was removed from the protective cover. The sponge was squeezed out above the lesion and for 5 minutes the solution was allowed to diffuse inside the caries lesion. Between the applications the teeth were stored in AFNOR NF S91-141 artificial saliva prepared according to standard procedure.

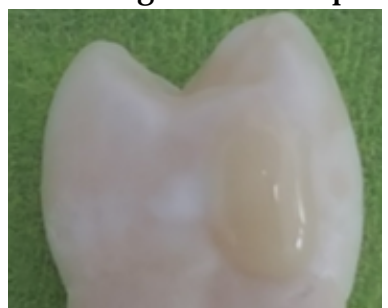

Fig. 2. The aspect of one white spot lesion covered on one half by selfadhesive flowable composite resin

\section{Hardness evaluation}

The teeth were cut on two mesio-distally cutting lines using diamond disks under cooling water, perpendicularly to the extern surface of the lesions, in order that both areas (negative control and study) to be evaluated. The opposite proximal sound enamel on each section served as positive control. The subsurface microhardness of the enamel samples was determined using digital microhardness tester (MicroVickers Hardness System CV- 400DMTM, CV Instruments Namicon). A $50 \mathrm{~g}$ load weight was applied through a Vickers indenter. On horizontal tooth sections indentations were made in six areas for each sample: first area was placed $25 \mu \mathrm{m}$ bellow the extern surface (A1), the second one at $75 \mu \mathrm{m}$ bellow the extern surface (A2), the third one at $125 \mu \mathrm{m}(\mathrm{A} 3)$, the forth one at $175 \mu \mathrm{m}$ bellow the extern surface (A4), the fifth at $225 \mu \mathrm{m}$ bellow the extern surface (A5) and the last one extended up to 275 $\mu \mathrm{m}$ (A6) (fig. 3). In each area of the sample three indentation were made in horizontal line. The microhardness was determined by measuring the lengths of the diagonals of the indentation marks and expressed as a Vickers Hardness Number (VHN). For each area of one sample the VHN value was reported as the average of three determinations. The final value of one area was the average of ten samples determination.

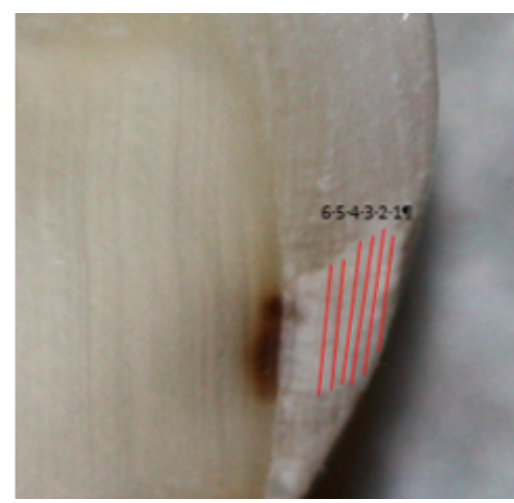

Fig. 3. The lines (1-6) where indentations were made to establish the enamel hardness on each lesion

\section{Data statistical analyse}

Kolmogorov Smirnov test was used to establish the distribution of data in groups (sig. 2-tailed $>0.05$ ). Significant differences of data in study group when compared to negative and positive control were determined by paired sample t test ( $95 \%$ confidence interval of the differences, $p>0.05$ ). 


\section{Results and discussions}

The VHN values at different depth levels in acute (white spot) lesions are presented in table 1 . In both negative control and study groups the VHN values increased from A1 to A6 areas. In study group VHN values were higher than in negative control group irrespective of the area. The lowest VHN value was registered in negative control $A 1$ area and the highest in study group A6 area. In all six areas of investigation, VHN values in negative control and study groups were lower than the values in positive control group.

The VHN values at different depth levels in chronic (brown spot) lesions are presented in table 2. Increased VHN values from $A 1$ to $A 6$ were registered in both negative control and study groups. Increased VHN values were obtained in study group when compared to negative control group, irrespective of the area of investigation. The lowest VHN value was registered in negative control al area and the highest in study group A6 area.

Kolmogorov Smirnov test results showed normal distribution of data in all groups $(p \geq 0.05)$ (table 3$)$.

\begin{tabular}{|c|c|c|c|}
\hline \multicolumn{4}{|c|}{ VHN \pm standard deviation for white spot lesions in the absence or } \\
in presence of remineralization \\
\hline Area & Negative control & Study & Positive control \\
\hline A1 & $63.30 \pm 8.12$ & $98.50 \pm 6.98$ & $365.20 \pm 19.60$ \\
\hline A2 & $93.20 \pm 6.71$ & $143.30 \pm 10.29$ & $352.30 \pm 18.22$ \\
\hline A3 & $142.50 \pm 8.14$ & $258.20 \pm 7.56$ & $348.20 \pm 9.62$ \\
\hline A4 & $204.20 \pm 11.00$ & $278.70 \pm 10.07$ & $345.50 \pm 13.83$ \\
\hline A5 & $237.40 \pm 11.20$ & $293.10 \pm 9.59$ & $346.70 \pm 11.45$ \\
\hline A6 & $260.60 \pm 14.70$ & $321.50 \pm 15.68$ & $342.40 \pm 22.76$ \\
\hline
\end{tabular}

\begin{tabular}{|c|c|c|c|}
\hline \multicolumn{4}{|c|}{ VHN \pm standard deviation for brown spot lesions in the absence or in } \\
presence of remineralization
\end{tabular}

Table 3

KOLMOGOROV SMIRNOV TEST RESULTS IN ALL GROUPS

\begin{tabular}{|c|c|c|c|c|c|c|c|c|c|c|c|c|}
\hline \multirow[b]{4}{*}{ Groups } & \multicolumn{12}{|c|}{ Kolmogorov Smimov test- sig. 2-tailed } \\
\hline & \multicolumn{6}{|c|}{ White spot lesions } & \multicolumn{6}{|c|}{ Brown spot lesions } \\
\hline & \multicolumn{6}{|c|}{ Area } & \multicolumn{6}{|c|}{ Area } \\
\hline & A1 & A2 & $\mathrm{A3}$ & A4 & A5 & A6 & A1 & $\mathrm{A} 2$ & $\mathrm{~A} 3$ & A4 & A5 & A6 \\
\hline $\mathrm{NC}$ & 0.208 & 0.930 & 0.984 & 0.930 & 0.978 & 0.954 & 0.996 & 0.978 & 0.984 & 09986 & 0.974 & 1.000 \\
\hline $\mathrm{S}$ & 0.994 & 0.372 & 0.997 & 1.000 & 0.649 & 1.000 & 0.932 & 0.955 & 0.997 & 1.000 & 0.999 & 0.919 \\
\hline $\mathrm{PC}$ & 0.999 & 0.877 & 0.984 & 0.991 & 0.998 & 1.000 & 0.999 & 0.971 & 1.000 & 0.841 & 0.953 & 0.974 \\
\hline
\end{tabular}

\section{Table 4}

STATISTICAL PAIRED SAMPLES TEST RESULTS OF DATA COMPARISON BETWEEN STUDY, NEGATIVE CONTROL AND POSITIVE CONTROL GROUPS FOR WHITE SPOT LESIONS

\begin{tabular}{|c|c|}
\hline Compared groups & $\begin{array}{l}\text { Paired samples test sig. (2- } \\
\text { tailed) }\end{array}$ \\
\hline SA1-NCA1 & 0.000 \\
\hline$S A 2-N C A 2$ & 0.000 \\
\hline$S A 3-N C A 3$ & 0.000 \\
\hline S A4-NC A4 & 0.000 \\
\hline SA5-NC A5 & 0.000 \\
\hline S A6-NC A6 & 0.000 \\
\hline SA1-PCA1 & 0.000 \\
\hline $\mathrm{SA} 2-\mathrm{PC} A 2$ & 0.000 \\
\hline $\mathrm{SA} 3-\mathrm{PC} A 3$ & 0.000 \\
\hline $\mathrm{SA} 4-\mathrm{PC} A 4$ & 0.000 \\
\hline SA5-PCA5 & 0.000 \\
\hline SA6-PC A6 & 0.017 \\
\hline $\begin{array}{l}\text { S- study group; NC- } \\
\text { positive control grou }\end{array}$ & control group; PC- \\
\hline
\end{tabular}

\begin{tabular}{|c|c|}
\hline Compared groups & $\begin{array}{c}\text { Paired samples test } \\
\text { sig. (2-tailed) }\end{array}$ \\
\hline S A1 - NC A1 & 0.000 \\
\hline S A2 - NC A2 & 0.000 \\
\hline S A3 - NC A3 & 0.000 \\
\hline S A4 - NC A4 & 0.000 \\
\hline S A5 - NC A5 & 0.000 \\
\hline S A6 - NC A6 & 0.000 \\
\hline SA1 - PCA1 & 0.000 \\
\hline SA2 - PC A2 & 0.000 \\
\hline SA3 - PC A3 & 0.000 \\
\hline SA4-PCA4 & 0.000 \\
\hline SA5 - PCA5 & 0.000 \\
\hline SA6 - PC A6 & 0.064 \\
\hline $\begin{array}{l}\text { S- study group; NC- negative control } \\
\text { group; PC- positive control group }\end{array}$ \\
\hline
\end{tabular}

Table 5

STATISTICAL PAIRED SAMPLESTEST RESULTS OF DATA COMPARISON BETWEEN STUDY, NEGATIVE CONTROL AND POSITIVE CONTROL GROUPS FOR WHITE SPOT LESIONS 
hydroxyapatite crystals formation on the surface of P11-4 fibres [22, 23]. Previous studies have shown that $P$ 4 can penetrate into the micro pores of enamel white spotlesions surface due to its low viscosity and that can trigger a process of self assembly and to generate a bioactive scaffold that determines in situ deposition of the mineral [17]. These findings might explain the increased hardness values after P11-4 peptide application when compared to untreated areas in the present study. The same increase of enamel hardness after application of P11-4 peptide in artificial caries lesions were obtained by Soares et al. [24].

The ability of the peptide to induce biomimetic mineralisation by nucleating hydroxyapatite crystals and subsequently to re-harden the enamel was demonstrated by SEM analysis. On a study conducted by JablonskiMomeni A et al. [20], SEM images of the samples where self-assembling peptide P11-4 were applied showed large areas of remineralization of the enamel surface in $93 \%$ of the samples.

In the currentstudy we followed the protocol of hardness evaluation of the caries lesion starting at $25 \mu \mathrm{m}$ from the top of the surface, as Schmidlin etal. [25] did in their study. This was motivated by the fact that the samples are fragile and the uncovered enamel surface would break when starting to make the indentation at $10 \mu \mathrm{m}$ below the enamel surface. It was demonsrated by Schmidlin et al. [25] that when applied on artificial caries lesions, selfassembling peptides can improve the rehardening of these lesions even in the deeper leyers of the lesion. Despite the increased values of hardness especially at $175 \mu \mathrm{m}$, at $225 \mu \mathrm{m}$ and at $275 \mu \mathrm{m}$ from the surface of the lesions in our study, the hardness values are decreased when compared to sound enamel.

In a clinical trial, Brunton et al. [17] aimed to evaluate the efficiency of P11- 4 self assembling peptide when applied on cervical incipient caries lesions. Significantly change in lesions colour was observed in the first 8 days after treatment, but the size and progression of the lesions improved significantly in the day 30 after treatment. The study also pointed that the improvement in size and progression was maintained 6 month after a single application. Clinical performance of P11 - 4 peptide on noncavitated initial proximal caries lesions treatment was demonstrated by Schlee M. etal. [26]. Twelve months after the treatment, visual evaluation demonstrated a major shift toward regression of the initial lesions and the combination of visual and radiographic and digital subtraction analyses showed regression in $71 \%$ of the caries lesions, $0.14 \%$ of the lesions being unchanged and $0.14 \%$ steel progressing. The first-in-man published trial suggested that mineral deposition around P11- 4 matrix appears within 3-6 months [17]. In Schlee study [26] 12-month follow-up results confirm and complete previous data regarding the medium term success and stability of incipient caries lesion treatment using P11-4. In another clinical study was evaluated the efficiency of P11- 4 when used in occlusal initial caries lesions on erupting permanentmolars by visual examination and laser fluorescence assessment. At three month and six month recalls, significantly caries lesions stage and activity regression was observed [27].

Due to the fact that regeneration mechanism of P11-4 relies on natural remineralization provided by saliva, factors like saliva quantity (salivary flow rate) and quality (mineral content, $p \mathrm{H}$ ) are extremely important in establishing the individual response to the therapy. In our study artificial saliva was used, with constant parameters regarding calcium and phosphate ions concentration and $\mathrm{pH}$. Future in vivo studies are needed to evaluate the effectiveness of this peptide in incipient caries lesions treatment.

\section{Conclusions}

Using self-assembling peptides as a remineralization agent on white spot and brown spot caries lesions significantly improve the hardness of these lesions even in all layers of the lesions. With the exception of brown spot lesions in deepest area ( $275 \mu \mathrm{m}$ below the surface of the lesions), the hardness of all white spot and brown spot lesions were far from reaching the hardness of sound enamel.

\section{References}

1. COCHRANE, N.J ., CAI, F., HUQ, N.L., BURROW, M.F., REYNOLDS, E.C., J. Dent. Res., 89, 2010, p. 1187.

2. AKIN, M., BASCIFTCI, F.A., Angle Orthod., 82, 2012, p. 770.

3. MINI, K.J., BABU, A., GOPINATHAN A.S., Int. J. Comm. Med. Public Health., 2, 2015, p. 10.

4. STOLERIU, S., IOVAN, G., GEORGESCU, A., SANDU, A.V., ROSCA, M., ANDRIAN, S., Rev. Chim. (Bucharest), 63, no. 1, 2012, p. 68.

5. STOLERIU, S., IOVAN, G., PANCU, G., GEORGESCU, A., SANDU, A.V., ANDRIAN, S., Rev. Chim. (Bucharest), 63, no. 11, 2012, p. 1120.

6. NIDHI, G., KUNWARJ EET, S., J. Pharm. Biomed. Sci., 24, 2012, p. 79.

7. TEN CATE, J.M., Eur. J. Oral Sci., 105, 1997, p. 461.

8. BALAN, A., ANDRIAN, S., SAVIN, C., SANDU, A.V., PETCU, A., STOLERIU, S., Rev. Chim. (Bucharest), 66, no. 4, 2015, p.562.

9. ANDRIAN, S., IOVAN, G., GHIORGHE, C.A., PANCU, G., GEORGESCU, A., ANTONESCU, D.N., STOLERIU, S., Rev. Chim. (Bucharest), 68, no.1, 2017, p. 134.

10. PANCU, G., ANDRIAN, S., MOLDOVANU, A., NICA, I., SANDU, A.V., STOLERIU, S., Mat. Plast., 51, no. 4, 2014, p. 428.

11. STOLERIU, S., IOVAN, G., GHIORGHE, C.A., NICA, I., PANCU, G., GEORGESCU, A., ANDRIAN, S., Rev. Chim. (Bucharest), 66, no. 11, 2015, p.1772.

12. GAVRILA, L., MAXIM, A., BALAN, A., STOLERIU, S., SANDU,A.V., SERBAN, V., SAVIN, C., Rev. Chim. (Bucharest), 66, no. 8, 2015, p. 1159.

13. SOMANI, R., JAIDA, S., SINGH, D.J ., ARORA, V., J . Oral Biol. Craniofac. Res. 4, 2014, p.104.

14. AGGELI, A., BELL, M., BODEN, N., KEEN, J.N., KNOWLES, P.F., MC LEISH, T.C.B., PITKEATHLY, M., RADFORD, S.E., Nature, 386, 1997, p.259.

15. KYLE, S., AGGELI, A., INGHAM, E., MCPHERSON, M.J., Biomaterials, 31, 2010, p. 9395.

16. MAUDE, S., TAI, L.R., DAVIES, R.P.W., LIU, B.; HARRIS, S.A., KOCIENSKI, P.)., AGGELI, A., Top Curr. Chem., 310, 2012, p. 27.

17. BRUNTON, P.A., DAVIES, R.P.W., BURKE, J.L., SMITH, A., AGGELI, A., BROOKES, S.J ., KIRKHAM, J., Brit. Dent. J., 215, 2013, p. e6. DOI: 10.1038/sj.bdj.2013.741

18. BROSELER, F., TIETMANN, C., SCHLEICH, R., DRECHSEL, T., BOMMER, C., Clin. Oral Investig., 17, 2013, p. 1055.

19. SCHLEE, M., RATHE, F., Clin. Oral Investig., 17, 2013, p. 1046.

20. J ABLONSKI-MOMENI, A., HEINZEL-GUTENBRUNNER, M., J. Orofac. Orthop., 75, 2014, p. 175.

21. KIRKHAM, J., FIRTH, A., VERNALS, D., BODEN, N., ROBINSON, C., SHORE, R.C., BROOKES, S.J., AGGELI, A., J. Dent. Res., 86, 2007, p. 426.

22. KIND, L., STEVANOVIC, S., WUTTIG, S., WIMBERGER, S., HUG, M., PIELES, U., J Dent Res. 96, 2017, p. 790.

23. DEYHLE, H., DZIADOWIEC, I., KIND, L., THALMANN, P., SCHULZ, G., MÜLLER, B., Dent. J., 3, 2015, p. 111.

24. SOARES, R., DE NORONHA DE ATAIDE, I., FERNANDES, M., LAMBOR, R., J. Clin. Diagn. Res., 11, no. 4, 2017, ZC136-ZC141. doi: 10.7860/J CDR/2017/23594.9758.

25. SCHMIDLIN, P., ZOBRIST, K., ATTIN, T., WEGEHAU, F., J. Appl. Oral Sci., 24, no. 1, 2016, p. 31.

26. SCHLEE, M., SCHAD, T., KOCH, J.H., CATTIN, P.C., RATHE, F., J. Invest. Clin. Dent., 9, 2018, e12286. DOI: 10.1111/jicd.12286.

27. ALKILZY, M., SANTAMARIA, R.M, SCHMOECKEL, J., SPLIETH, C.H., Adv. Dent. Res., 29, no. 1, 2018, p. 42.

Manuscript received: 19.12 .2018 